\title{
Determination of the Glucosidase-Stimulating Proteins by Competitive Enzyme-Linked Immunoassay
}

\author{
SubHaSh C. DATTA AND NoRMaN S. RADIN \\ Mental Health Research Institute, University of Michigan, Ann Arbor, Michigan 48109
}

Received February 7, 1984

\begin{abstract}
A procedure for the immunoassay of cohydrolase sphingolipid-I in mouse tissue is described. This cohydrolase (actually a mixture of at least four related proteins) stimulates or activates the $\beta$-glucosidase which hydrolyzes ceramide glucoside, a widely occurring glycosphingolipid. The method involves extraction of cohydrolase from tissuc homogenate with a salt-buffer solution, removal of proteins by adjustment to $\mathrm{pH} \mathrm{6,} \mathrm{further} \mathrm{removal} \mathrm{of} \mathrm{proteins} \mathrm{by} \mathrm{heating,}$ and removal of interfering materials with a small size exclusion column. Antibodies were raised to bovine cohydrolase in rabbits and purified with an affinity column made from cohydrolase. The immunoassay involves binding of antibody by the cohydrolase sample $(20-200 \mathrm{pg})$ in competition with cohydrolase that has been chemically linked to horseradish peroxidase. The mixture is treated with particle-linked second antibody and centrifuged; the pellet is then assayed fluorometrically for peroxidase content. Initial application of the method showed that cohydrolase was present in all mouse tissues studied and that its concentration paralleled that of glucocerebrosidase relatively closely. Changes with age (14 and 92 days) occurred in a similar fashion for the two substances. (c) 1984 Academic Press. Inc.

KEY WORDS: glucocerebrosidase stimulator; immunoassay for cohydrolase SPH-I; cohydrolase distribution in mouse tissues; glucocerebrosidase distribution in mouse tissues; changes with age.
\end{abstract}

The term cohydrolase has been proposed as a generic term for the proteins which stimulate or augment the activity of various hydrolytic enzymes (1). The stimulator named cohydrolase SPH-I ${ }^{1}$ acts on glucosylceramide glucosidase. It was discovered by Ho and O'Brien (2) in the spleen of a patient suffering from a genetic insufficiency of the enzyme activity (Gaucher disease). It occurs in normal spleen at a much lower level and evidently accumulates during the course of the disease, which also produces accumulation of the enzyme's substrate, glucocerebroside. The activator has been isolated from bovine (3) and human $(1,4)$ spleen, and has

\footnotetext{
' Abbreviations used: SPH, sphingolipid; CHS-I, cohydrolase SPH-I; PBS, 5 mM Na phosphate, pH 7, in 500 $\mathrm{mM} \mathrm{NaCl}$; $\mathrm{ggG}$, immunoglobulin $\mathrm{G}$; $\mathrm{BSA}$, bovine serum albumin; $\mathrm{CNBr}$, cyanogen bromide.
}

been found to consist of at least four heatstable, electrophoretically separable proteins of very low molecular weight (1). Later work showed that cohydrolase SPH-I (CHS-I) also stimulates sphingomyelinase and galactosylceramide galactosidase (5).

The species-specificity of CHS-I seems to be low. Bovine CHS-I stimulates human and mouse glucosidases, and human CHS-I stimulates the bovine enzyme (3).

Antibodies have been induced in rabbits, using the bovine CHS-I as antigen, and found to react to a similar degree with all four glucocerebroside cohydrolases of Gaucher spleen (1). Initial tests with a plastic-plate binding assay showed that the antibodies also reacted with mouse extracts, suggesting that it would be possible to devise an immunoassay useful for physiological studies of cohydrolase levels. 


\section{MATERIALS AND METHODS}

Buffer A (5 mM Na phosphate, pH 7.0, in $40 \mathrm{mM} \mathrm{NaCl}$ ) was used for storing most samples. Crude glucocerebrosidase was isolated from bovine spleen (3) and assayed with methylumbelliferyl- $\beta$-glucoside as substrate. Tritium-labeled substrate ( $N$-stearoyl$\left[6-{ }^{3} \mathrm{H}\right] \mathrm{glucosylsphingosine)}$ was prepared synthetically (6). Hsd mice were from Harlan Sprague Dawley, Indianapolis, Indiana.

Sample volumes at the microliter level were dispensed with a 5-, 10-, or 50- $\mu 1 \mathrm{mi}-$ crosyringe. This allowed us to use relatively concentrated solutions and was important for preventing losses of CHS-I by adsorption onto containers (7). Vortexing for long periods of time ( $5 \mathrm{~min}$ or more) was done with the Kraft Big Vortexer (Glas-Col Apparatus, Terre Haute, Ind.), a large vortexer which holds test tubes in a rack. We made a rack for $1.5-\mathrm{ml}$ polypropylene centrifuge tubes by repeatedly pushing a tube into a rectangular block of foam plastic.

Preparation of antibody. The IgG in the serum from one of the rabbits (1) was isolated with a column containing DEAE Affi-Gel Blue (Bio-Rad Laboratories, 153-7307). This is a beaded, crosslinked agarose containing diethylaminoethyl groups and covalently bound Cibacron Blue F3GA (8). The serum $(6 \mathrm{ml})$ was dialyzed against $20 \mathrm{mM}$ Tris $-\mathrm{Cl}^{-}$, pH 8.0 , in $28 \mathrm{mM} \mathrm{NaCl}$, and passed through the $1.8 \times 18-\mathrm{cm}$ packing previously equilibrated with the same buffer. The IgG in the effluent (same buffer) was assayed in plastic titer wells by binding bovine CHS-I to the plastic, binding the antibodies to the CHS-I, and binding peroxidase-linked anti-rabbit IgG to the rabbit $\operatorname{IgG}(1)$. The active proteins were found to elute as a single peak, monitored at $280 \mathrm{~nm}$, between 36 and $210 \mathrm{ml}$. Half-maximal color in the peroxidase assay $(0.26 \mathrm{~A})$ was reached with about $275 \mathrm{ng}$ of the protein in the pooled fractions.

A second protein-containing peak was eluted with $20 \mathrm{mM}$ Tris- $\mathrm{Cl}^{-}, \mathrm{pH} 8.0$, containing $1.4 \mathrm{M} \mathrm{NaCl}$. This peak yielded only the basal color in the titer-well assay at sample weights up to $1000 \mathrm{ng}$. The same negative reaction was obtained with the two peaks from control (nonimmune) serum from the same rabbit.

The active fraction was concentrated by pressure ultrafiltration with an Amicon PM10 membrane and dialyzed against PBS. The yield was $28.6 \mathrm{mg}$ of protein, based on the BSA standard in the copper-Folin reagent assay (9).

The antibodies reacting with CHS-I were isolated from the IgG mixture with an affinity column $(3.8 \times 15 \mathrm{~mm})$ made from $200 \mu \mathrm{g}$ of bovine CHS-I and $100 \mathrm{mg}$ of CNBractivated Sepharose 4B (7) in PBS. Various amounts of IgG (1.8 to $4.55 \mathrm{mg})$ were passed through the packing in 0.5 to $2 \mathrm{ml}$ of PBS. Nonspecific IgG was eluted with $6 \mathrm{ml}$ of PBS and bound $\operatorname{lgG}$ was eluted with $3 \mathrm{ml}$ of $1 \mathrm{M}$ HOAc in $0.5 \mathrm{M} \mathrm{NaCl}$ (this solution had a $\mathrm{pH}$ of 2.6). A flow rate of $5 \mathrm{ml} / \mathrm{h}$ was used and $0.5-\mathrm{ml}$ fractions were collected. The acidic fractions were promptly adjusted to pH 7 with 2 M Tris base, pooled after assay, and dialyzed against PBS during vacuum ultrafiltration (p-Micro-ProDiCon Model 10, Bio-Molecular Dynamics, Ore.).

The affinity column had a maximal binding capacity for the specific IgG of about $0.3 \mathrm{mg}$ ( $8 \%$ of the crude IgG) and the recovery of protein in the two peaks was about $90 \%$ when a $3.7-\mathrm{mg}$ sample was added to the column. In the titer-well assay for antibodies, the first protein fraction showed only the blank level of color in the peroxidase assay, while the specific fraction yielded half-maximal color at about $75 \mathrm{ng}$ of IgG. Comparing this value with the corresponding value obtained after the Cibacron Blue step (275 ng), we see an enrichment in specific IgG of 3.7fold. Based on the yield from the affinity column, however, the enrichment appears to be 12.5-fold.

Preparation of peroxidase-labeled CHS-I. Horseradish peroxidase $(8 \mathrm{mg}$, Sigma Chemical Co., Type VI) was oxidized with periodate and linked to $2 \mathrm{mg}$ of bovine CHS-I by 
reduction with borohydride (10). The conjugate, plus excess peroxidase, was separated from unreacted CHS-I with a column of Sephadex G-100 $(1.6 \times 80 \mathrm{~cm})$ in $50 \mathrm{mM}$ Tris- $\mathrm{AcO}^{-}, \mathrm{pH}$ 7.3. Elution was monitored by the ability of CHS-I, even in the conjugated form, to stimulate glucosidase activity $(3,11)$. The first active fraction was pooled and mixed with human serum albumin $(10 \mathrm{mg} /$ $\mathrm{ml}$ ) and then stored in $0.2-\mathrm{ml}$ portions at $-20^{\circ} \mathrm{C}$.

Immunoassay for CHS-I. The method used (10) involves mixing an unknown or standard amount of CHS-I with a standardized amount of CHS-I conjugated with peroxidase. To this is added purified $\operatorname{lgG}$ (too little to bind all the antigen). The antibody-antigen complex is precipitated with agarose-bound goat antibodies against rabbit IgG (Miles Laboratories), and the pellet is assayed for peroxidase content with 3-( $p$-hydroxyphenyl)propionic acid, a fluorogenic substrate (12). The reaction sequence is carried out in a $1.5-\mathrm{ml}$ polypropylene conical tube with attached cap, and all materials involved in immunological binding are diluted with $0.2 \mathrm{M}$ Tris- $\mathrm{AcO}^{-}$, pH 7.3, containing $0.05 \%$ human serum albumin and $0.05 \%$ Tween 20 . To each tube is added (in the order shown) $20 \mu$ leach of CHS-I (0-200 pg), IgG (100 ng), and CHSI-peroxidase (stock solution diluted 500 -fold). The competitive binding proceeds $16 \mathrm{~h}$ at $4^{\circ} \mathrm{C}$, after which $0.2 \mathrm{ml}$ of agarose-goat antibodies is added, enough to bind about $6.6 \mu \mathrm{g}$ of rabbit $\mathrm{IgG}$. The tubes are vortexed $10 \mathrm{~min}$ and then incubated for $3 \mathrm{~h}$ at $4^{\circ} \mathrm{C}$. The suspension is centrifuged at $13,000 \mathrm{~g}$ for $3 \mathrm{~min}$ and the pellet is washed twice with 1 $\mathrm{ml}$ of $50 \mathrm{~mm}$ Tris-acetate, $\mathrm{pH} \mathrm{7.3}$; each time the pellet is vortexed $5 \mathrm{~min}$.

The enzyme content in the final pellet is assayed by adding $1 \mathrm{ml}$ of $50 \mathrm{~mm}$ Tris$\mathrm{AcO}^{-}, \mathrm{pH} 7.3,50 \mu \mathrm{l}$ of $3 \mathrm{~mm}$ hydrogen peroxide, and $50 \mu \mathrm{l}$ of $30 \mathrm{mM}$ hydroxyphenylpropionic acid and vortexing slowly for 1 $\mathrm{h}$. Then $50 \mu \mathrm{l}$ each of $0.2 \mathrm{M} \mathrm{KCN}$ and $1 \mathrm{M}$ $\mathrm{NaOH}$ is added and the tubes are vortexed $5 \mathrm{~min}$ and then stored at $4^{\circ} \mathrm{C}$ for $16 \mathrm{~h}$. After brief centrifugation, the fluorescence in the supernatants is measured at $405 \mathrm{~nm}$ (excitation at $320 \mathrm{~nm}$ ).

The Tris buffers were prepared at room temperature.

Assay for glucosylceramide glucosidase activity. This was done with mouse tissue homogenates prepared in $5 \mathrm{mM}$ Na phosphate, $\mathrm{pH} \mathrm{7,} \mathrm{using} 4 \mathrm{mg}$ of liver or $6 \mathrm{mg}$ of other tissues. The procedure (14) involves a 1-h incubation of labeled lipid in Triton X-100, taurocholate, and citrate-phosphate, $\mathrm{pH}$ 5.4, followed by solvent partitioning to isolate the radioactive glucose. The specific activities were independent of tissue weight (up to 6 $\mathrm{mg}$ ) and time (up to $1 \mathrm{~h}$ ).

\section{RESULTS}

\section{Immunoassay Sensitivity}

The relationship between weight of pure CHS-I and binding ratio exhibited excellent linearity and precision between 20 and 200 pg protein (Fig. 1).

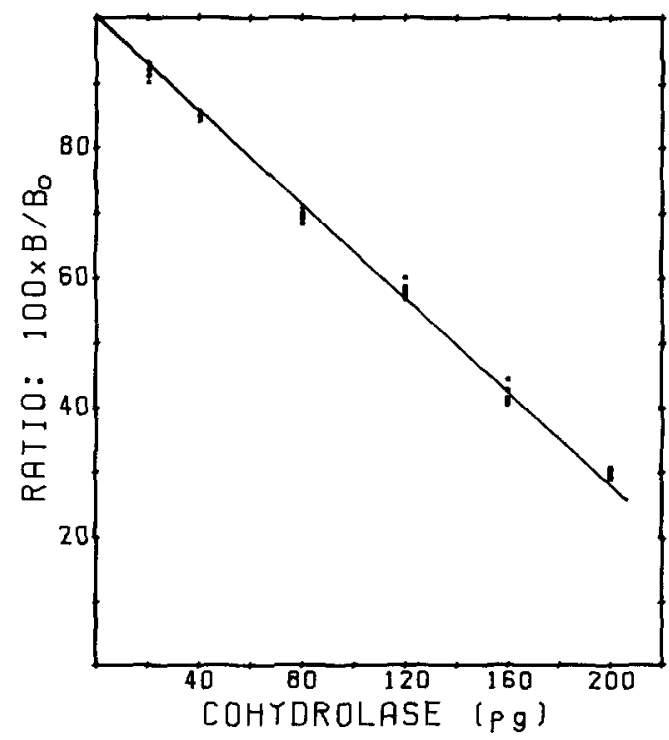

FIG. 1. Relationship between weight of bovine cohydrolase SPH-I and ratio of observed enzyme activities (fluorescence readings). The value $B$ is the peroxidase activity when cohydrolase is added to the system; $B_{0}$ is the activity when cohydrolase is absent. The points shown for each weight indicate the values observed on 7 different days, and the line connecting them is a composite of the seven standardization curves. 
Extraction of CHS-I from Tissues

Since CHS-I occurs in membranes as well as in cytosol of spleen (3), and since it binds to glucocerebrosidase (7), it was necessary to determine an appropriate extraction method. This was tested by homogenizing liver from 120-day mice with a Brinkmann Polytron in $10 \mathrm{vol}$ of $5 \mathrm{mM}$ phosphate, $\mathrm{pH} 7$, or $0.1 \mathrm{M}$ glycine chloride, $\mathrm{pH} 3$. The homogenates were adjusted to pH 6 with $2 \mathrm{M}$ HOAc or $1 \% \mathrm{Na}_{2} \mathrm{HPO}_{4}$, kept at $4^{\circ} \mathrm{C}$ for $10 \mathrm{~min}$, and centrifuged at $25,000 \mathrm{~g}$ for $20 \mathrm{~min}$. The clear, dark brown supernatant was promptly transferred to a screw-cap glass tube, heated 5 min in boiling water, cooled in ice, and centrifuged at $10,000 \mathrm{~g}$ for $15 \mathrm{~min}$. This supernatant was then analyzed by the immunoassay method.

Maximal CHS-I content was observed when the liver was extracted with $\mathrm{pH} 7$ buffer containing $1 \mathrm{M} \mathrm{NaCl}$ (Table 1). At any NaCl concentration, the addition of Triton X-100

\section{TABLE 1}

EFFECTS OF DIFFERENT ExTRACTING SOLUTIONS ON COHYDROLASE YIELD

\begin{tabular}{lc}
\hline \multicolumn{1}{c}{ Extractant } & $\begin{array}{c}\text { CHS-I content } \\
\text { (ng/mg) }\end{array}$ \\
\hline (A) $5 \mathrm{mM}$ Phosphate, pH $7,80 \mathrm{~mm}$ & \\
$\mathrm{NaCl}$ & 3.90 \\
(B) A + Triton X-100, 1 mg/ml & 3.96 \\
(C) Phosphate buffer + 440 mM NaCl & 4.56 \\
(D) C + Triton & 4.61 \\
(E) Phosphate buffer + $1.04 \mathrm{M} \mathrm{NaCl}$ & 5.47 \\
(F) E + Triton & 5.49 \\
(G) E + 8 M urea & 2.01 \\
(H) G, but not heated at $100^{\circ} \mathrm{C}$ & 2.32 \\
(I) 100 mM Glycine-Cl', pH 3 & 1.83 \\
(J) I, but pH not adjusted to 6 & 0.71 \\
\hline
\end{tabular}

Note. At least two different tissue weights were assayed in duplicate and the results averaged. Minced, pooled livers were homogenized with the solutions described above, adjusted to pH 6, and centrifuged. The supernatants were then heated in boiling water for $5 \mathrm{~min}$, cooled, and centrifuged, and the supernatant was assayed for CHS-I content.
TABLE 2

EFFECT OF EXTRACTION pH ON YIELD OF COHYDROLASE

\begin{tabular}{|c|c|c|c|c|}
\hline pH & $\begin{array}{l}\text { Volume of } \\
\text { sample } \\
(\mu \mathrm{l})\end{array}$ & $\begin{array}{c}\text { Amount of } \\
\text { cohydrolase } \\
\text { (pg) }\end{array}$ & $\begin{array}{l}\text { Concentration } \\
\text { of cohydrolase } \\
\text { (ng/mg liver) }^{a}\end{array}$ & $\begin{array}{c}\text { Relative } \\
\text { yield } \\
(\%)^{b}\end{array}$ \\
\hline \multirow[t]{3}{*}{6.5} & 1 & $35 / 35$ & 3.84 & \multirow{3}{*}{85} \\
\hline & 2 & $69 / 70$ & 3.82 & \\
\hline & 3 & $106 / 106$ & 3.88 & \\
\hline \multirow[t]{3}{*}{6.0} & 1 & $41 / 41$ & 4.53 & \multirow{3}{*}{100} \\
\hline & 2 & $82 / 80$ & 4.45 & \\
\hline & 3 & $128 / 126$ & 4.65 & \\
\hline \multirow[t]{3}{*}{5.5} & 1 & $30 / 31$ & 3.35 & \multirow{3}{*}{75} \\
\hline & 2 & $61 / 62$ & 3.38 & \\
\hline & 3 & $95 / 94$ & 3.46 & \\
\hline \multirow[t]{3}{*}{5.0} & 1 & $10 / 11$ & 1.15 & \multirow{3}{*}{23} \\
\hline & 2 & $19 / 19$ & 1.05 & \\
\hline & 3 & $27 / 27$ & 0.99 & \\
\hline \multirow[t]{3}{*}{4.5} & 1 & $4 / 4$ & 0.44 & \multirow{3}{*}{11} \\
\hline & 2 & $10 / 10$ & 0.55 & \\
\hline & 3 & $15 / 16$ & 0.57 & \\
\hline
\end{tabular}

Note. The $\mathrm{pH}$ of the liver homogenate was adjusted with acetic acid, centrifuged, heated to $100^{\circ} \mathrm{C}$, and centrifuged again. The supernatant was purified by size exclusion and the active fraction analyzed by immunoassay.

average of duplicate measurements.

${ }^{b}$ Average of six measurements, relative to the maximum value.

had no effect. The dissociating agent, urea, and a low initial $\mathrm{pH}$ were both poor.

Since previous trials with bovine spleen had shown a strong dependence on extraction $\mathrm{pH}$ at low salt concentrations (3), this matter was studied in greater detail with mouse liver. Homogenization with phosphate at $\mathrm{pH}$ 7 and the other steps listed above were used, but the $\mathrm{pH}$ after homogenization was adjusted to 4.0-6.5 instead of 6.0. In this experiment, the CHS-I extract was purified additionally, prior to assay, by passing $0.3 \mathrm{ml}$ of the supernatant through a $7 \times 160-\mathrm{mm}$ column of Sephadex G-75 (see next section). CHS-I was determined in 1-, 2-, and 3- $\mu$ l aliquots of the CHS-I fraction (corresponding to 9.1, 18.2, and $27.3 \mu \mathrm{g}$ of liver). The results (Table 2) show a remarkable sensitivity to extraction $\mathrm{pH}, 6.0$ being best. The table also shows good proportionality to sample volume and good replication with duplicate samples. 


\section{Removal of Interfering Materials}

When various amounts of liver were assayed for CHS-I content using the heated extract, the apparent concentration was seen to decrease with tissue weights greater than $14 \mu \mathrm{g}$. The maximal observed CHS-I concentration in the smallest aliquots was about 5.9 $\mathrm{ng} / \mathrm{mg}$, but it decreased to $3.9 \mathrm{ng} / \mathrm{mg}$ with a 27.3- $\mu$ g sample of liver. Recovery tests with added pure bovine CHS-I gave values between 60 and 83\%. Accordingly, an additional purification step was applied, as in the method used for CHS-I isolation (3).

A $7 \times 160-\mathrm{mm}(6.2 \mathrm{ml})$ column of Sephadex G-75, particle size (dry) $40-120 \mu \mathrm{m}$, was prepared in buffer A. A 0.3-ml sample of heated liver extract, prepared as above at pH 6, was passed through the column at 3 $\mathrm{ml} / \mathrm{h}$ and eluted with more of the same buffer. As expected from our knowledge of bovine and human CHS-I behavior on such a column $(1,3)$, the first $2 \mathrm{ml}$ contained no detectable CHS-I, the next $3 \mathrm{ml}$ contained the CHS-I, and the last $4 \mathrm{ml}$ was inactive. Good proportionality between liver weight and CHS-I content was found, with aliquots of column effluent equivalent to 4.55-36.4 $\mu \mathrm{g}$ of liver (Table 3). To test for the presence of interfering materials, we added $80 \mathrm{pg}$ of pure bovine CHS-I to similar aliquots, prior to the size exclusion step, and found good recovery with samples corresponding to liver samples up to $27.3 \mu \mathrm{g}$ (Table 3, right column).

Table 3 also shows the severe interference with the assay due to materials in fractions $A$ and $C$, which explains the need for the gel permeation step.

Another recovery test was made by adding bovine CHS-I to part of the initial liver homogenate, at the ratio of $4.51 \mathrm{ng} / \mathrm{mg}$ tissue, which almost doubled the amount of CHS-I in the aliquots. The supplemented and nonsupplemented samples were centrifuged, heated, and purified by gel permeation as above, and then three different aliquots were assayed from each active column fraction (Table 4). These samples also showed good

TABLE 3

LIVER CONTENT OF COHYDROLASE SPH-I AND RECOVEY OF ADDED COHYDROLASE

\begin{tabular}{cccccc}
\hline Fraction & $\begin{array}{c}\text { Aliquot } \\
\text { assayed } \\
(\mu \mathrm{l})\end{array}$ & $\begin{array}{c}\text { Amount } \\
\text { found } \\
(\mathrm{pg})\end{array}$ & $\begin{array}{c}\text { Calculated } \\
\text { concentration } \\
(\mu \mathrm{g} / \mathrm{g} \text { liver })\end{array}$ & $\begin{array}{c}\text { Amount found } \\
\text { after adding CHS-I } \\
(\mathrm{pg})\end{array}$ & $\begin{array}{c}\text { Recovery of } \\
\text { added CHS-I } \\
(\%)\end{array}$ \\
\hline \multirow{2}{*}{$\mathrm{A}$} & 1 & 0 & 0 & 36 & 45 \\
& 5 & 0 & 0 & 12 & 15 \\
& 10 & 0 & 0 & 7 & 9 \\
B & $5^{a}$ & 24 & 5.3 & 102 & 98 \\
& $10^{a}$ & 46 & 5.1 & 124 & 98 \\
& $4^{b}$ & 90 & 5.0 & 166 & 93 \\
& $6^{b}$ & 132 & 4.8 & 206 & 80 \\
& $8^{b}$ & 180 & 4.9 & 244 & 58 \\
& 1 & 0 & 0 & 46 & 30 \\
& 1 & 0 & 0 & 24 & 18 \\
\hline
\end{tabular}

Note. Fractions $\mathrm{A}, \mathrm{B}$, and $\mathrm{C}$ are the first, middle, and final fractions $(2,3$, and $4 \mathrm{ml}$, respectively) obtained from a Sephadex G-75 column, $7 \times 160 \mathrm{~mm}$. The column was loaded with extract from $27.3 \mathrm{mg}$ of mouse liver and eluted at $3 \mathrm{ml} / \mathrm{h}$. For the interference experiments, $80 \mathrm{pg}$ of bovine CHS-I was added before assay to duplicate aliquots from the column fractions.

${ }^{a}$ Column effluent first diluted 10-fold with assay buffer.

${ }^{b}$ Column effluent first diluted 2-fold. 
TABLE 4

Recovery of Cohydrolase Added to Liver Homogenate, 4.51 pg/ag Liver, Prior to pH Adjustment, HEATING, AND SEPHADEX ChromatograPHY

\begin{tabular}{ccccc}
\hline $\begin{array}{c}\text { Aliquot } \\
\text { assayed } \\
(\mu \mathrm{g})\end{array}$ & $\begin{array}{c}\text { Amount } \\
\text { found } \\
(\mathrm{pg})\end{array}$ & $\begin{array}{c}\text { Calculated } \\
\text { concentration } \\
(\mathbf{n g} / \mathbf{m g} \text { liver })\end{array}$ & $\begin{array}{c}\text { Amount found } \\
\text { after adding CHS-I } \\
(\mathbf{p g})\end{array}$ & $\begin{array}{c}\text { Recovery of } \\
\text { added CHS-I } \\
(\mathbf{\%})\end{array}$ \\
\hline 9.1 & 47 & 5.2 & 86 & 95 \\
9.1 & 48 & 5.3 & 87 & 95 \\
18.2 & 93 & 5.1 & 168 & 92 \\
18.2 & 92 & 5.1 & 168 & 93 \\
27.3 & 130 & 4.8 & 238 & 88 \\
27.3 & 130 & 4.8 & 238 & 88 \\
\hline
\end{tabular}

Note. Duplicate aliquots, three different amounts, were analyzed from each column.

proportionality and recovery of added CHS$\mathrm{I}$, although some loss or interference could be seen at $27.3 \mu \mathrm{g}$ of liver. However, the total CHS-I content from the supplemented sample (238 pg) was calculated by extrapolating from the high end of the calibration curve (Fig. 1), so a low value can be expected.

\section{Specificity of the Antibodies against CHS-I}

The possibility always exists that some tissue proteins can react nonspecifically with the $\mathrm{IgG}$ isolated from immunized rabbits. While our IgG was purified by two highly specific chromatographic steps, and the samples were freed of heat-insolubilized protein, we nevertheless examined the heat-stable liver extract in greater detail. A taller Sephadex column $(1.54 \times 32 \mathrm{~cm})$ was prepared and loaded with $3 \mathrm{ml}$ of extract, as in the standard method. Fractions of $2 \mathrm{ml}$ each were collected, at a flow rate of $15 \mathrm{ml} / \mathrm{h}$, and monitored at $280 \mathrm{~nm}$. As found with bovine spleen, the absorbance measurements showed an early peak, a low flat region, and a large late peak. Most of the CHS-I eluted in the intermediate low region. Immunoassay for CHS-I and evaluation of the glucocerebrosidase-stimulating activity showed single, somewhat coincident peaks for both measurements (Fig. 2).

The concentration of CHS-I in each column fraction was calculated by the two assay methods, and the ratio of the two values, shown at the top of Fig. 2, was found to be close to 1 at all points along the peaks. The observed fluctuations are reasonable, considering the precision of the two measurements.

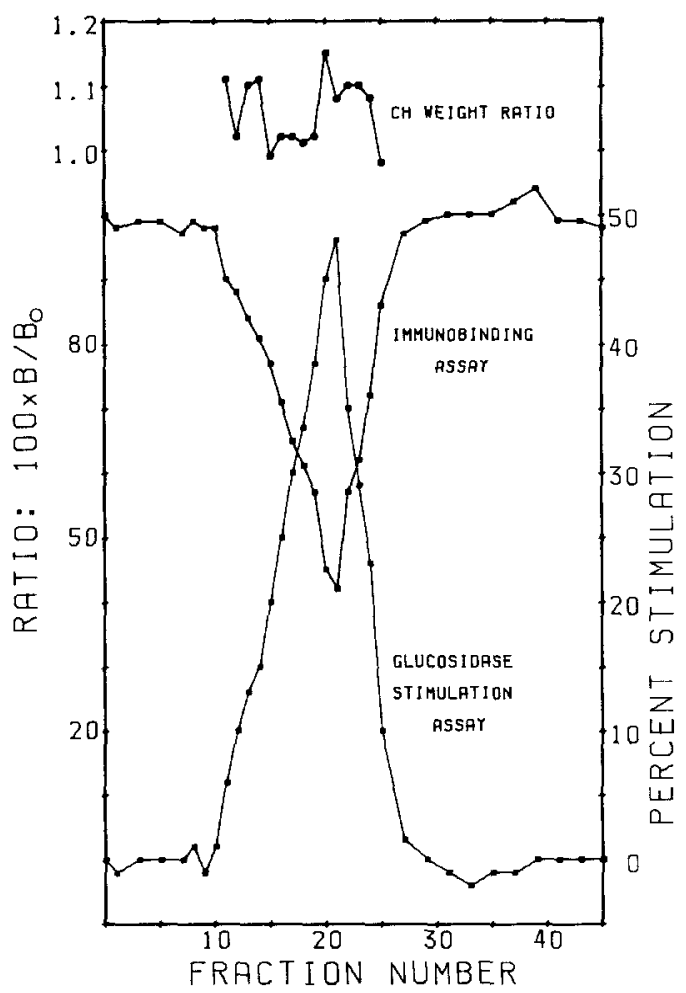

FiG. 2. Analysis of the cohydrolase in fractions obtained from a gel permeation column (Sephadex G-75). One curve shows the results obtained in the immunoassay, and the other shows the results obtained in the cerebrosidase-stimulation assay. The curve at the top was derived by calculating the content of cohydrolase by both methods, dividing one by the other. 
Thus, by definition of CHS-I as a glucosidase stimulator, the immunoassay seems to measure only CHS-I. It is possible, of course, that a high-molecular-weight pro-form of CHS-I exists in tissues, but this might be discarded by the heating or extraction step.

Glew and Coffee recently reported that calmodulin from bovine brain has a weak stimulating activity with glucocerebrosidase from human liver (13). Our immunoassay method was applied to this protein (from bovine liver, Sigma Chemical Company, P2277) and found to give a negative response with samples up to $1000 \mathrm{pg}$. Evidently calmodulin and CHS-I are unrelated.

\section{Distribution of CHS-I and \\ Glucocerebrosidase in Mouse Tissues}

If the primary role of CHS-I is to activate cerebroside glucosidase, one might expect the two to be distributed similarly among different organs. They have already been shown to have a similar distribution between spleen subcellular membrane fractions (3). In this first use of the immunoassay, we examined six tissues, pooled from ten 14-day mice in two groups of five each (Table 5). In this experiment, CHS-I was determined in two different aliquots derived from 9.1 and 27.3 $\mu \mathrm{g}$ of tissue, each run in duplicate, the four values being averaged for use in Table 5 . Liver was found to contain the highest concentration of CHS-I and enzyme activity; heart and lung contained the lowest concentrations. The maximum range was 3.6 to 1 for glucosidase and 4.5 to 1 for CHS-I. The concentration of CHS-I in spleen was about half the values we found for bovine spleen (by isolation).

The ratio of enzyme specific activity to CHS-I content (0.82 to 1.13$)$ was strikingly similar for all organs. (There is no significance to the actual numerical value, which is based on arbitrary units.) Comparison of the two values for each organ on successive lines shows good agreement, considering that two different groups of mice were analyzed. The glucosidase activities were similar to those reported for CF-1 mice at age 16 (14).

The same study with older mice (92 days) showed that both the enzyme activity and

TABLE 5

Comparison of Cohydrolase Concentration with Glucocerebrosidase SPECIFIC ACtivity IN TISSUES OF 14- AND 92-DAY-OLD MICE

\begin{tabular}{lcccccc}
\hline & Liver & Spleen & Brain & Kidney & Heart & Lung \\
\hline CHS-I (ng/mg tissue) & & & & & & \\
$\quad$ 14 days old & 3.64 & 1.76 & 1.57 & 1.23 & 0.81 & 0.81 \\
& 3.58 & 1.78 & 1.53 & 1.16 & 0.80 & 0.82 \\
92 days old & 4.48 & 1.83 & 1.36 & 1.24 & 0.55 & 0.63 \\
& 4.61 & 1.92 & 1.24 & 1.09 & 0.63 & 0.66 \\
Glucosidase (nmol/h/mg) & & & & & & \\
14 days old & 3.02 & 1.76 & 1.38 & 1.37 & 0.85 & 0.81 \\
& 2.90 & 1.56 & 1.44 & 1.32 & 0.80 & 0.90 \\
92 days old & 3.83 & 1.96 & 1.17 & 1.14 & 0.52 & 0.68 \\
& 4.10 & 1.88 & 1.16 & 1.15 & 0.59 & 0.75 \\
Ratio ${ }^{a}$ (enzyme/CH) & & & & & & \\
14 days old & 0.82 & 0.94 & 0.91 & 1.13 & 1.02 & 1.05 \\
92 days old & 0.87 & 1.03 & 0.90 & 0.98 & 0.94 & 1.11 \\
\hline
\end{tabular}

Note. Each value shown is the average of duplicate assays from one column run; each line is derived from the pooled organs from a group of five mice.

${ }^{2}$ Each ratio was calculated from all eight values for one organ. 
CHS-I level increased with age in liver and spleen (the two organs that destroy blood cells) and decreased in brain, heart, and lung (Table 5). The two levels changed with age in very similar fashions so that the ratios remained the same. Liver was consistent in possessing the lowest enzyme/CHS-I ratio at both ages.

\section{DISCUSSION}

We attribute the high precision and linearity exhibited by the immunoassay procedure described here to the use of several features: (a) antibodies that have been "sorted" by the immunopurification step to have similar binding constants; (b) reduction in adsorptive losses by the use of relatively concentrated solutions, which are dispensed with positive displacement microliter syringes; (c) avoidance of variable, nonspecific wall-binding methods and nonspecific rabbit plasma proteins; and (d) a method of small-vessel mixing which is unusually thorough (a multiple-vial vortexer).

Since CHS-I seems to activate two additional sphingolipid hydrolases (5), it will be of interest to see if there is a similar parallelism for these enzymes.

\section{ACKNOWLEDGMENTS}

We are indebted to Dr. S. S. Iyer for the preparation of the peroxidase-CHS-I conjugate and to Inez Mason for many kinds of assistance. Dr. Kate Barald, Department of Anatomy and Cell Biology, kindly made her Titertek Multiskan colorimeter available to us. This work was supported in part by Grant NS-03192 from the National Institutes of Health.

\section{REFERENCES}

1. Iyer, S. S., Berent, S. L., and Radin, N. S. (1983) Biochim. Biophys. Acta 748, 1-7.

2. Ho, M. W., and O'Brien, J. S. (1971) Proc. Natl. Acad. Sci. (USA) 68, 2810-2813.

3. Berent, S. L., and Radin, N. S. (1981) Arch. Biochem. Biophys. 208, 248-260.

4. Peters, S. P., Coyle, P., Coffee, C. G., Glew, R. H., Kuhlenschmidt, M. S., Rosenfeld, L., and Lee, Y. C. (1977) J. Biol. Chem. 252, 563-573.

5. Wenger, D. A., Sattler, M., and Roth, S. (1982) Biochim. Biophys. Acta 712, 639-649.

6. McMaster, M. C., Jr., and Radin, N. S. (1977) $J$. Labelled Compd. Radiopharm. 13, 353-357.

7. Berent, S. L., and Radin, N. S. (1981) Biochim. Biophys. Acta 664, 572-582.

8. Bio-Rad Laboratories (1983) Bulletin 1062.

9. Lowry, O. H., Rosebrough, N. J., Farr, A. L., and Randall, R. J. (1951) J. Biol. Chem. 193, 265275.

10. Shinomiya, Y., Kato, N., Imazawa, M., and Miyamoto, K. (1982) J. Neurochem. 39, 1291-1296.

11. Radin, N. S., and Berent, S. L. (1982) in Methods in Enzymology (Ginsburg, V., ed.), Vol. 83, Part D, pp. 596-603, Academic Press, New York.

12. Zaitsu, K., and Ohokura, Y. (1980) Anal. Biochem. 109, 109-113.

13. Glew, R. H., and Coffee, C. J. (1984) Arch. Biochem. Biophys. 229, 55-63.

14. Hara, A., and Radin, N. S. (1979) Biochim. Biophys. Acta 582, 412-422. 